Value". This was followed by the index to genera and species described in the Palaeontologia Indica; an index to the Records; and finally, the last proof reaching him just before his death, the index to the Memoirs. This series of publications is of inestimable value to all interested in Indian geology, and the Survey can congratulate itself on being the best documented service in existence. In addition, he prepared for the Geological Society a list of literature added to its library during the War period.

La Touche's interest in geology was very wide, and his knowledge was always at the disposal of any inquirer. His work is characterized by a minute attention to detail, a scrupulous accuracy of observation, and a strict regard for truth. He received no recognition from official nor from non-official bodies, but he has left behind him a record of a lifetime's work which can rarely have been equalled, and a lasting monument to his industry, the more surprising as he suffered throughout his career from greatly impaired sight.

La Touche married Miss Handy, an Irish lady of great charm, and had five children, two boys and three girls. One son was killed in the War while the other carries on the family tradition of service in the East as a member of the Burma Forest Service. To his widow and the surviving members of the family the sympathy of all his old colleagues is respectfully tendered.

G. H. TIPPER.

\section{Prof. John Taylor}

By the death of Prof. John Taylor on April 11, Irish engineering has lost one of its best known figures. Born near Gask, Perthshire, in 1865, he received his early engineering training in Glasgow at the Cowlairs Locomotive Works of the late North British Railway. In 1888 he won a Whitworth exhibition from the Anderson Technical College, Glasgow, and a Royal scholarship tenable at the Royal College of Science for Ireland, and proceeded to Dublin. He took the associateship of that College in 1891, after which he received a junior appointment on the staff and in 1902 became lecturer in engineering. In the University of Dublin, in 1903, he gained the large gold medal and senior moderatorship in experimental science. In 1929, a few years after the Royal College of Science for Ireland had been taken over by University College, Dublin, he was appointed professor of mechanical engineering in the National University of Ireland. About two years ago he received the degree of D.Sc. (honoris causa) of the National University.

Prof. Taylor did much work on the causes behind the failure of materials, and his technical advice was frequently sought by Irish public bodies. He conducted tests necessary for the planning of the dam in connexion with the proposed hydro-electric undertaking of the Liffey scheme at Poulaphouca, and carried out experiments with fish passes for the Shannon hydro-electric scheme. In recent years he devoted a considerable amount of his time to an investigation into the efficiency of turf burning appliances, a study which he undertook at the request of the Industrial Research Council of Eire, of which he was a member. His work in this connexion has already resulted in efficient domestic cooking ranges, suitable for the Irish turf consumer, being placed on the market.

In his teaching work, Prof. Taylor was noted for his thoroughness and enthusiasm. During his long career as a teacher a very large number of students passed through his hands, by all of whom he will be remembered as a man of the highest character with the most conscientious devotion to duty.

\section{Mr. F. J. Gould}

Mr. F. J. GouLd, who died on April 6, was one of the most devoted and persistent workers in the cause of humanism and world peace. He was borm in 1855 and kept up his activities in writing and speaking for his faith to within a few weeks of his death. He himself published annually an account of what he had done in the way of writing, editing and above all giving moral lessons to the young, and this amazing record moved large numbers of persons to subscribe to a sustentation fund which had become necessary for him when his uneasy relations with the London School Board came to an end in his early years. He had been an assistant master in East End elementary schools, and the kind of religious teaching which was required of teachers in those days was much more hotly debated than it is now in less dogmatic days. But Gould's ideal was never in doubt and never changed. He advocated from first to last the teaching of a sympathetic outline of the chief faiths of the world and the education of the young mainly by moral and historical lessons based on the admirable features of the past.

Gould had in early years been deeply influenced by the Englishmen, who, like Frederic Harrison, owed their spiritual direction to Auguste Comte. To this he added a strong socialist leaning and a faithful association for more than fifty years with those who defended the claims of free thought in the pages of the Literary Guide and elsewhere. His apostolic journeys took him over the greater part of the United States as well as India, while for many years he laboured as secretary for the International Congress of Moral Education. He acted in this capacity in London, The Hague, Geneva, Rome, Paris and Cracow. Before the Hitler régime he had been co-operating with liberal-minded Germans on a plan for an improved and more international method of teaching history. This perhaps was his deepest and most abiding motive.

Gould's mind was a rare compound of peaceful and loving appreciation of men and opinions of every type, combined with an unbending and untiring tenacity in promoting the type of thought to which as a young man of just over twenty he had given his allegiance. It may be safely predicted that one day-and not very far distant-his name and work will be more loudly acclaimed and recognized than they have been in the first days following his demise. F. S. Marvin. 